International Journal of Industrial Engineering Research and Development (IJIERD)

Volume 7, Issue 1, January-April 2016, pp. 10-23, Article ID: IJIERD_07_01_002

Available online at https://iaeme.com/Home/issue/IJIERD?Volume=7\&Issue $=1$

ISSN Print: 0976 - 6979 and ISSN Online: 0976 - 6987

DOI: https://doi.org/10.34218/IJIERD.7.1.2016.002

(C) IAEME Publication

\title{
AUTOMOTIVE PRODUCT DESIGN AND DEVELOPMENT OF CAR DASHBOARD USING QUALITY FUNCTION DEPLOYMENT
}

\author{
Praveen Padagannavar \\ School of Aerospace, Mechanical \& Manufacturing Engineering, \\ Royal Melbourne Institute of Technology, (RMIT University), \\ Melbourne, VIC 3001, Australia
}

\begin{abstract}
This report analyses Quality Function Deployment (QFD) on a car dash board. One of the business strategies is to know what basically wants from this product and helping them to achieve customer satisfaction. QFD is the best method to convert the customer requirements and needs into quality characteristic and develop a design quality product. In this report, the specification for choosing a dash board unit is analysed with customer's preference and converted into engineering characteristics. The voice of customer is taken as an initial step and rated on importance and the house of quality diagram is figured out by considering all the real time aspects. This report is defined to Quality Function Deployment of car dash board and the objectives are:
\end{abstract}

Customer view

Technical specification

Technological limit

Money saving analysis by using House of Quality Diagram

Key word: QFD, Car industry, Dash board, car dash board

Cite this Article: Praveen Padagannavar, Automotive Product Design and Development of Car Dashboard Using Quality Function Deployment, International Journal of Industrial Engineering Research and Development, 7(1), 2016, pp. 10-23.

https://iaeme.com/Home/issue/IJIERD?Volume=7\&Issue=1

\section{INTRODUCTION}

Car industry plays an important role as the back bone for the economy of any country. Dash board is one of the main parts of the car interior component and plays a very 
important role in different aspects such as safety, reliability, user friendly, technology and appearance and so on. Dash board used for operating different functions in the car such as instrumental panel, audio and video devices, holders, switches and glove box, these function distributed inside a vehicle that communicate with each other. Car dash board like the other components of the car have lots of improvement in terms of quality, extra features, material, updating the existing product to take the dash board at the new level. Around 1960's, the car dash board was designed basically form cheap material and with limited features, but now we can see that modern design and more features is very basic requirement for any type of car.

The main problem discussed in this report is that the kind of material used for car dash board in terms of texture, appearance and mass of the dash board. Secondly, the dash board should absorb the vibration when the car is at high speed. Lastly, one of the problems faced in ford vehicles are that the location of the USB port in the wrong place. The main aspects focused here are the problems faced by drivers because of material and wrong location of USB port, as well as the customers need better dashboard with new technology, material, design and innovation are timely being updated. The aim of this report is to study the development of car dashboard by providing improvement in existing product or add new functions to meet the customer needs and expectations. A proper dash board can satisfy the customer's needs and also increases the income for the company.

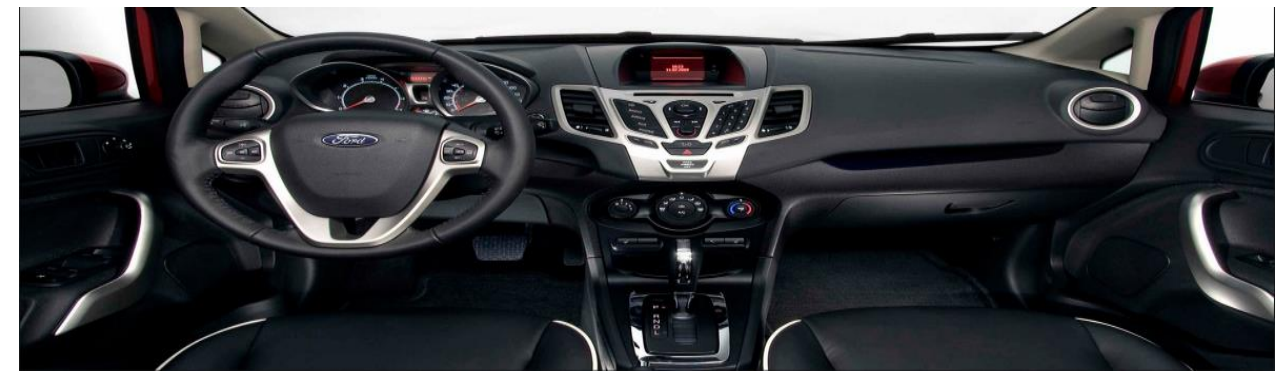

Figure 1 Dash board (Anon, (2015)

[Online] Available at:http://pu.edu.pk/images/journal/iqtm/PDF-FILES/paper-1Volume_VI_Issue-1-June-2010.pdf[Accessed 4 May 2015])

\section{PROBLEM DEFINITION}

Car dashboard is provided with suitable functions to make the driver comfortable and easy to drive. The progress of car dashboard and their changes in last few decades has had a significant impact on automotive industry in terms of technology, techniques and material required to design a car dashboard. In order to achieve these targets there are many practices going on in design and development and also maximizing the comfort satisfaction and minimizing the cost. The problem definition of this report is the development of car dashboard by providing new functions or modifying the present condition and meeting the customer requirements and expectations. Firstly, find the functions that need to modify in the car dashboard. Secondly, find the new features that needed to be incorporated in the car dashboard.

The kind of material used: - the material should be durable, texture of the plastic and material used for switches. The plastic used for dashboard should be free from hazardous material and should be environmental friendly. Mass: - In terms of mass the dashboard should be light weight and strong, this may also improve the fuel efficiency. Vibration observation: - the dashboard should absorb the vibration and 
should not produce noise with high speed and uneven roads. One of the problems found in recent ford vehicles is with the USB port. The USB port is inside the glove compartment, the storage area in dashboard. So while using the phone which is connected to the USB port with wire, the glove compartment door cannot be closed because the wire is in between the glove compartment and glove compartment door. Therefore, to overcome the existing problems we need to design next generation dashboard which has many advantages except cost, so by using quality function deployment we can improve design dashboard.

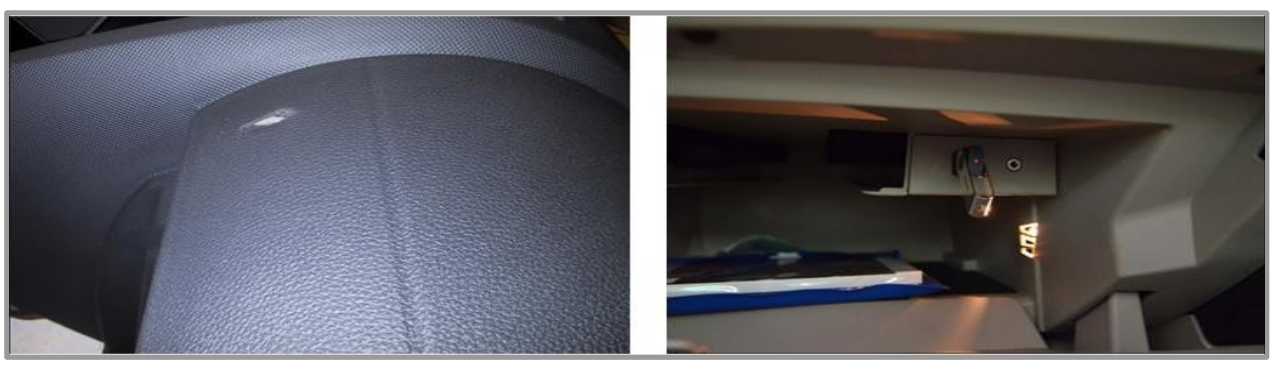

Figure 2 Problem definitions in car dash board (material \& USB port)

\section{SCOPE}

The scope of this report is to provide a customer with good dash board in which the customer can get comfortable use of electronic ports (USB) with suitable position and make the drive convenient. The customers need to provide with premium look of dash board by using quality material and make it more attractive to customers. The dash board should be provided with rigid and strong material and control the vibration in the cabin and make the drive more comfortable with noise free to the customers.

\section{METHODOLOGY}

The methodology selected for this report is Quality Function Deployment (QFD), Product Development and its strategies with the aim of Design and development of car dashboard by bringing improvement or add new function to meet the customer needs. Quality Function Deployment is an important development tool with wide range of applications to achieve product development, improve product quality and reduce the time and cost to design and manufacture the product. Quality Function Deployment is the platform for the customer's voice and specialist's voice.

QFD methods- "Deployment" steps: - Statements of Requirements $\rightarrow$ Design Plans $\rightarrow$ Manufacturing Plans $\rightarrow$ Process Control Plans.

\subsection{EXPECTED OUTCOME/ CONCEPT}

In order to advice a solution, we need to consider the latest technology, innovation, techniques and material and increase the comfort and convenience in automotive car dash board, with decreasing the amount of vibration and noise in the cabin. On the other hand, development of car dash board to meet the customer needs and expectations by improving the existing dash board or develop new one. To create a platform to have a conceptual solution, appropriate investigation is required by analysing data and information regarding to dash board comfort and convenience and as well as it should meet the customer needs and expectations.

One of the most important design features is to modify the electronic USB ports for the existing dash board and change the location in such a way that all the 
passengers in the car can be used accordingly. Another important feature is that, to give the dash board a premium look by selecting proper material and improve the texture, noise and strength.

The problems are taken into first consideration that is trim quality of car dash board and solve the problem by design principle.

- We can optimize the usage of material and save.

- We can achieve higher customer satisfaction.

- We can omit the parts/features which is not required for customer and save the material and cost.

- Customer will be satisfied because they get what they want and on the other hand, the company will saves money and generate income because they are developing the product according to the customer requirement.

- We can also limit the risk of environmental impact, by using suitable material.

The "Voice of the Company" is the next step, which outlines the technical specification of car dash board that must be coordinated with the voice of the customer. The company will carry out the voice of the customer through analysis and final car dash board model is developed ensuring customer needs. The expected outcome which is new developed car dashboard by production team will generate Quality function deployment matrix that will meet the customer's specifications.

\subsection{Affinity Diagram}

Customer requirements are organised in three groups by using affinity diagram. This affinity diagram will help us to identify customer requirements. Customer requirements are categorised and assured customer satisfaction. The market area tells us what to do and engineering area tells us how to do it.

Objective tree/ affinity diagram determines the breakdown of customer requirements in details. 

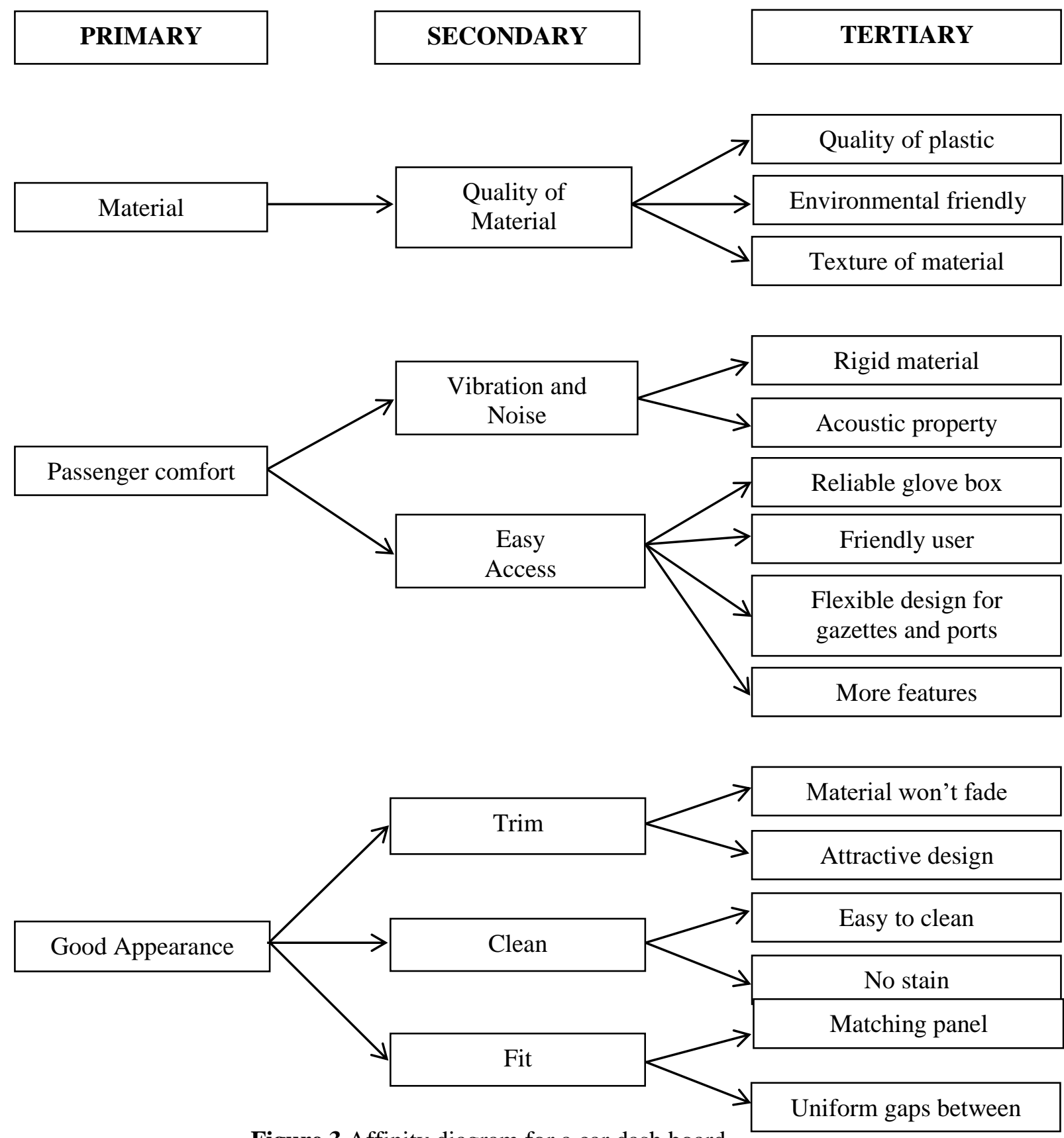

Figure 3 Affinity diagram for a car dash board

Further, two surveys should be conducted in this study. Survey 1 is conducted to figure out features or functions in the car dash board which needs to be improved. Survey 2 is conducted to know the voice of the customer about the features and function. Data collected form survey 1 and survey 2 is converted into customer needs. Customer needs is organised into preference. The next step is product development stage, the information gathered from the survey about customer requirement, technical specification and preferences will be useful to build the house of quality diagram for the car dash board. 
Table 1 voice of customer to customer needs

\begin{tabular}{|l|l|l|}
\hline \multicolumn{1}{|c|}{ VOICE OF THE CUSTOMER } & \multicolumn{1}{c|}{$\begin{array}{c}\text { ENGINEERING } \\
\text { CHARACTERISTIC }\end{array}$} & \multicolumn{1}{c|}{$\begin{array}{c}\text { CUSTOMER } \\
\text { NEEDS }\end{array}$} \\
\hline $\begin{array}{l}\text { Dash board and its functions should be easy to } \\
\text { use }\end{array}$ & Structure and geometry & User friendly \\
\hline Good ergonomics & Trim and finish & Good ergonomics \\
\hline Superior looks & Quality of material & Attractive design \\
\hline $\begin{array}{l}\text { Dash board plastic should have good texture } \\
\text { and rigid }\end{array}$ & $\begin{array}{l}\text { Type of plastic used and it's } \\
\text { weight }\end{array}$ & Good plastic quality \\
\hline $\begin{array}{l}\text { Dash board noise and vibration should be less } \\
\text { in the cabin }\end{array}$ & Acoustic properties & No vibration and noise \\
\hline $\begin{array}{l}\text { Electronic functions and USB ports should be } \\
\text { convenient to use }\end{array}$ & $\begin{array}{l}\text { Distance to access the } \\
\text { controls }\end{array}$ & $\begin{array}{l}\text { Comfortable and } \\
\text { convenient }\end{array}$ \\
\hline $\begin{array}{l}\text { Universal size glove box and no USB ports } \\
\text { inside }\end{array}$ & $\begin{array}{l}\text { Dimensions and Number of } \\
\text { components }\end{array}$ & Flexible design \\
\hline $\begin{array}{l}\text { It should not affect the existing features of the } \\
\text { dash board }\end{array}$ & Adjustable & $\begin{array}{l}\text { Not interfere with } \\
\text { vehicle operation }\end{array}$ \\
\hline Attachments for gazettes and other items & Dimensions & Multipurpose \\
\hline $\begin{array}{l}\text { The dash board spares should be easy to } \\
\text { replace }\end{array}$ & Cost of material & Saves time \\
\hline System should be durable and reliable & Operation cost & Reliable design \\
\hline
\end{tabular}

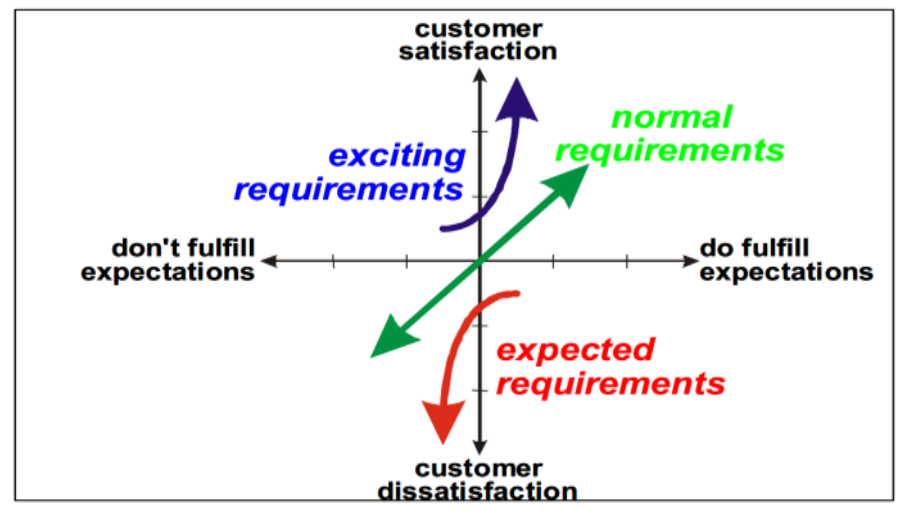

Figure 4 Voice of the Customer analysis (Kano's Modal) Reference for above figure: http://www.mazur.net/works/qfd_dfss.pdf

\subsection{House of Quality}

The customer attributes, engineering characteristic and technical specification are filled into house of quality, this relationship matrix will help us to get to know strong and weak point of the car dash board. This information will help manufacturer to know where the improvement of car dash board is needed and satisfy the customer. 


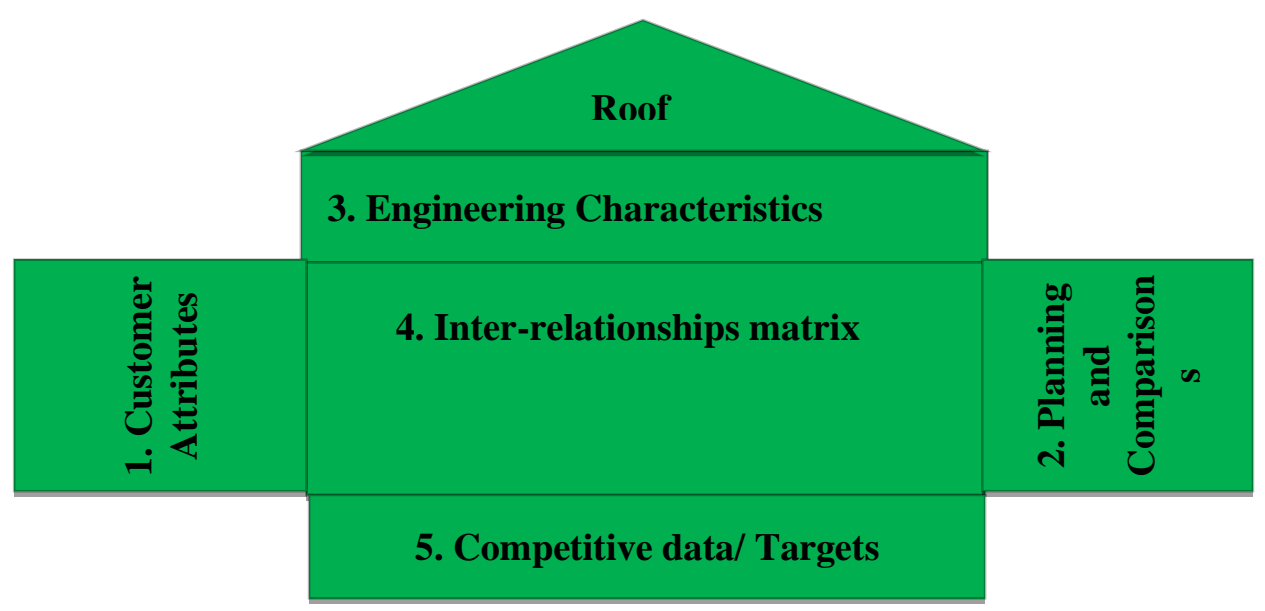

Figure 5 House of Quality

\subsection{WHAT, HOW and its Relationships}

The initial steps to implement the quality function deployment are to put the information together that is customer needs, technical specification and relationship between both customer needs and technical specification.

The ranking is been listed on the basis of customer feedback obtained from voice of customer and customer survey. The respective importance of the customer needs is shown in the below table. The final stage in identifying customer requirements is to reflect upon the results and process. The process of identifying the customer needs and method of collecting information is not the exact way it depends upon product to product and also depends on thinking approach of product development team. The below table 2 (WHAT'S) shows the importance of customer needs on the scale of 1 to 5 and in which 5 being the highest priority and 1 being the least priority. The below table 2 (WHAT'S) is ranked and rated according to the customer preferences. The information collected form the survey about customer requirements that is technical specification (HOW'S) is listed in the table 3 below according to the requirements.

Further, the table 4 also shows the relationship between WHAT'S and HOW'S which is used to build the house of quality matrix. The customer needs is mentioned in the below tables and have enough understanding to proceed on to the next development stage.

\subsection{What's Table}

Table 2 (WHAT'S) product importance rating table.

\begin{tabular}{|l|c|}
\hline \multicolumn{1}{|c|}{ CUSTOMER NEEDS (What's) } & IMPORTANCE \\
\hline Refined plastic material & 5 \\
\hline Attractive design & 3 \\
\hline Good ergonomics & 3 \\
\hline Less vibration and less noise in the cabin & 4 \\
\hline Rigid and strong material & 3 \\
\hline Durability & 1 \\
\hline Texture and colour of the plastic & 3 \\
\hline Wear and tear resistance & 2 \\
\hline Scratch proof & 2 \\
\hline
\end{tabular}




\begin{tabular}{|l|l|}
\hline User friendly dash board & 3 \\
\hline Comfortable and convenient USB ports to use & 5 \\
\hline Reliable design/ flexible design & 4 \\
\hline Structure / geometry / mechanism & 3 \\
\hline Efficient operating system & 5 \\
\hline Updated instrumental and dash board & 1 \\
\hline
\end{tabular}

\subsection{How's Table}

Table 3 list of How's for car dash board

\begin{tabular}{|l|l|}
\hline \multicolumn{1}{|c|}{ How's } & \multicolumn{1}{c|}{ UNITS } \\
\hline Dimension & $\mathrm{mm}$ \\
\hline Material quality & Subjective \\
\hline Distance to access & $\mathrm{mm}$ \\
\hline Number of components & Subjective \\
\hline Design and modify & Subjective \\
\hline Adjustable ports and switches & Subjective \\
\hline Area of the glove box & $\mathrm{mm}^{\wedge} 2$ \\
\hline Operation time & $\mathrm{Seconds}$ \\
\hline Depth of the container & $\mathrm{mm}$ \\
\hline Spring stiffness & $\mathrm{N} / \mathrm{m}$ \\
\hline Clamping force & $\mathrm{Newton}$ \\
\hline Diameter & $\mathrm{mm}$ \\
\hline
\end{tabular}

\subsection{Relationship between How's and What's}

Table 4 Relation between WHAT'S and HOW'S.

\begin{tabular}{|c|c|c|c|c|c|c|c|c|c|c|c|c|}
\hline WHAT, & مै & 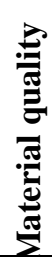 & 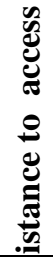 & 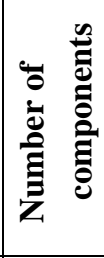 & 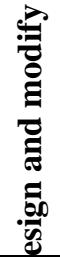 & 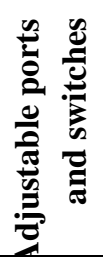 & 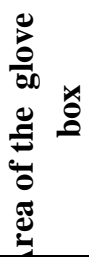 & 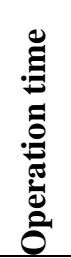 & 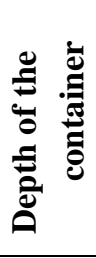 & 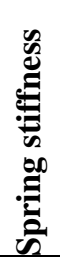 & 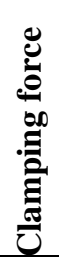 & \\
\hline $\begin{array}{c}\text { Refined plastic } \\
\text { material }\end{array}$ & & $\bullet$ & & & 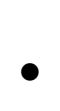 & & & & & & & \\
\hline Attractive design & • & • & • & • & • & & • & & • & & & • \\
\hline Good ergonomics & • & • & • & & & & & & & • & • & • \\
\hline $\begin{array}{l}\text { Less vibration and } \\
\text { noise }\end{array}$ & $\bullet$ & $\bullet$ & & & & & & & & $\bullet$ & & \\
\hline $\begin{array}{l}\text { Rigid, strong and } \\
\text { durability } \\
\text { material }\end{array}$ & & & & & & & & & & & & \\
\hline
\end{tabular}




\begin{tabular}{|c|c|c|c|c|c|c|c|c|c|c|c|c|}
\hline WHAT, & & 离 & 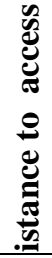 & 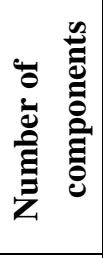 & 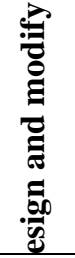 & 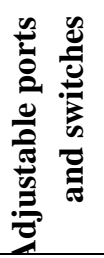 & 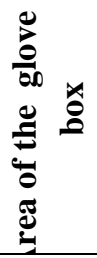 & 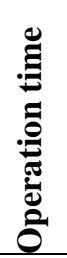 & 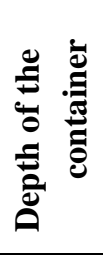 & 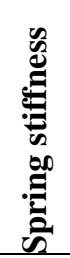 & 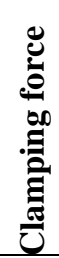 & \\
\hline $\begin{array}{l}\text { Texture and } \\
\text { colour of the } \\
\text { plastic }\end{array}$ & & • & & & $\bullet$ & & & & & & & \\
\hline $\begin{array}{l}\text { Scratch and wear } \\
\text { and tear } \\
\text { resistance }\end{array}$ & $\bullet$ & • & & & & & & & & & & \\
\hline $\begin{array}{l}\text { User friendly dash } \\
\text { board }\end{array}$ & $\bullet$ & & $\bullet$ & & $\bullet$ & $\bullet$ & & & $\bullet$ & & $\bullet$ & • \\
\hline $\begin{array}{c}\text { Comfortable and } \\
\text { convenient } \\
\text { USB ports }\end{array}$ & • & & $\bullet$ & & $\bullet$ & $\bullet$ & & & • & & & • \\
\hline $\begin{array}{l}\text { Reliable and } \\
\text { flexible design }\end{array}$ & $\bullet$ & $\bullet$ & $\bullet$ & $\bullet$ & & & & & & $\bullet$ & $\bullet$ & \\
\hline $\begin{array}{l}\text { Updated } \\
\text { instrumental } \\
\text { and dash } \\
\text { board }\end{array}$ & $\bullet$ & & & $\bullet$ & & & & $\bullet$ & & & & $\bullet$ \\
\hline $\begin{array}{l}\text { Efficient operating } \\
\text { system }\end{array}$ & & & $\bullet$ & $\bullet$ & & & & $\bullet$ & & & & \\
\hline
\end{tabular}

The above analysis reflects usefulness of the quality function of deployment analysis in identifying the product requirements that should be changed in arranged to give a good design for dash board that meets customers' needs and expectation and this also helps to analyse concept generation and selection phases.

\section{ANALYSIS}

The analysis done on the car dash board first is to understand customer perspective in order to provide appropriate design features. First of all the customer information should be collected. We get structured and quantitative information's such as surveys, customer tests and other is random and qualitative information such as visitors, vendors, employees and suppliers. Then HOQ matrix is simplified and analysed.

Once the customer requirements and technical specification characteristics are placed in the house of quality matrix, the product development team engineers will find the relation between them and figure out the solutions accordingly. 
Engineering characteristics rating is calculated according to the value of the customer importance and the relationship symbols value. Each symbol holds the value, the value 5 means strong, 3 medium and 1 for weak. The ratings are calculated by adding each column of the product of the customer importance rating and value to correlation symbol. The data that has been collected and organised must be analysed and value must be finalised.

\section{Areas in which company lack in and can catch the competitors}

After analysing the house of quality matrix, it is understood that material quality is the highest priority because most of the customer requirements associated with the attractive design, texture, colour, wear and tear resistance and scratch proof which is linked to material quality. The second highest priority is dimensions and rigid structure because customer needs is less vibration and less noise and strong dash board. The third priority is user friendly dash board and convenient use of USB ports because customer wants the ports should be used comfortably, reliable and flexible design and efficient operating system are related to distance to access.

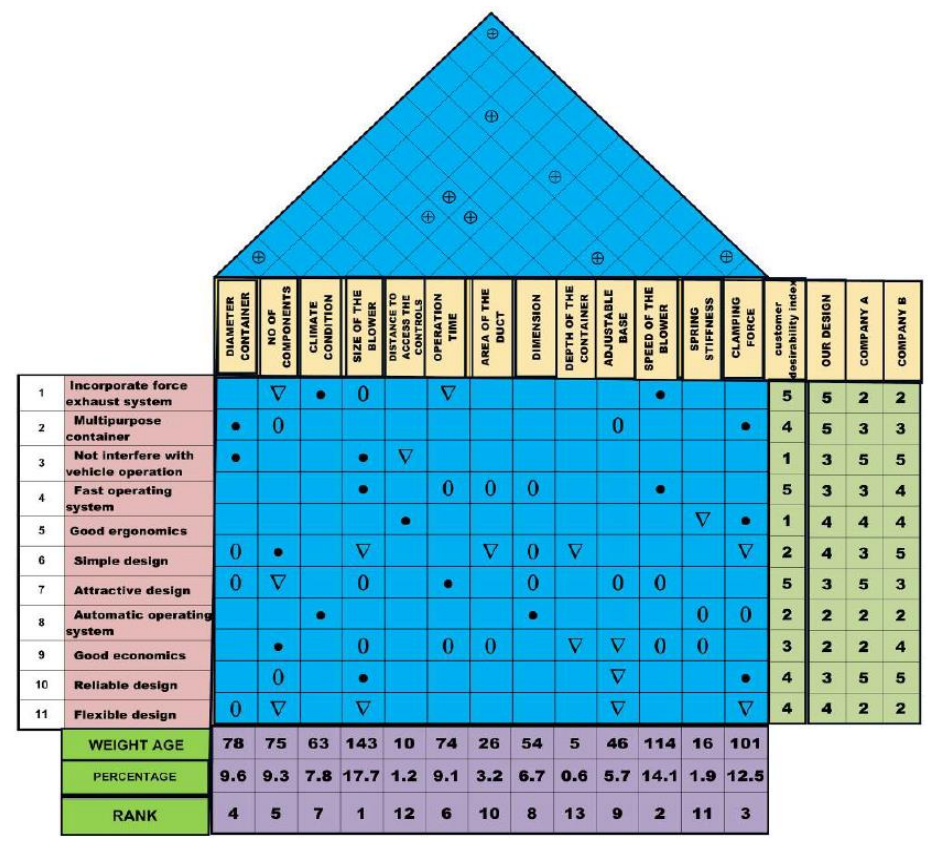

Figure 7 House of Quality Diagram

Anon, (2015). [Online] Available at: http://pu.edu.pk/images/journal/iqtm/PDF-

FILES/paper-1-Volume_VI_Issue-1-June-2010.pdf[Accessed 18 May 2015].

\subsection{Product Generation Phase}

The product generation phase is a process based on the results of HOQ diagram. The following steps are selected for product generation phase:

1. Clarification of problem: it is done by the functional decomposition of the system.

2. Development of design criteria: the following criteria should be kept in mind during product generation phase of the car dash board such as easy to use, minimum number of parts, easy to manufacture, efficient operating system, should not affect the vehicle performance, user friendly and low operating and manufacturing cost. 
Automotive Product Design and Development of Car Dashboard Using Quality Function Deployment

3. Schematic diagram of the concept: the diagram and working concept should be clearly understood.

4. Computer Aided design (CAD) model or any other software of the product: the models should be designed by using software's and modified accordingly.

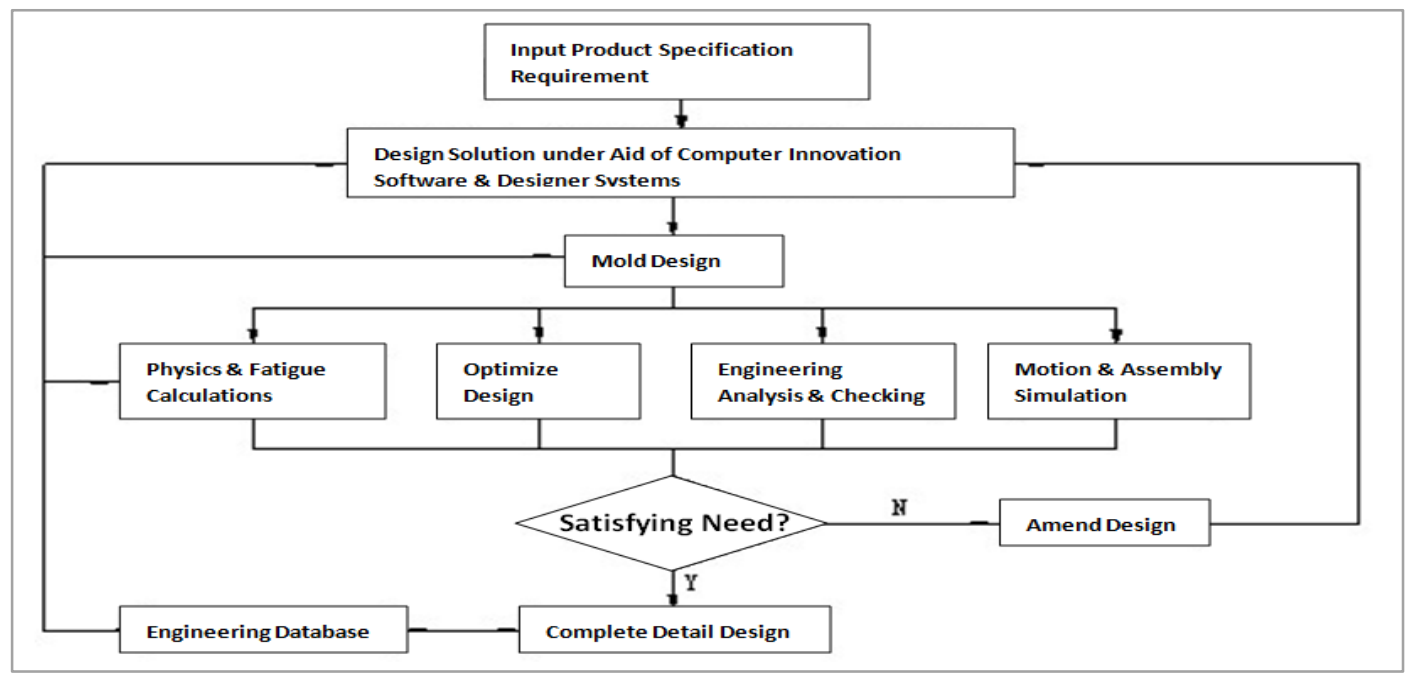

Figure 8 flow chart to develop new car dash board/ product using CAD/other software design

http://www.rs-online.com/designspark/electronics/blog/content-89.

\subsection{Design Team Focus on (Design Element Criteria)}

- The most important customer segment in terms of business strategy and marketing strategy.

- Most important area of customer needs and satisfaction.

- Which needs do competitors satisfy better.

- Strong correlation between needs meeting criteria and design element.

- Design elements have strong correlation with multiple important needs.

\section{DISCUSSION OF ANALYSIS}

To meet customer needs and requirements as much as possible, the major planning tool we used to find customer opinion is the house of quality matrix. This tool helped us to identify and translate the customer's voice into the design requirements and match the customer's needs. To achieve high level technical specification of customer needs is one of the best business strategies. From the evaluation and analysis we have understood the areas from the house of quality matrix where the company need to modify or change their design to satisfy the customers.

Areas to be improved by the company from the customer point of view or on the basis of customer priority:

1. The main aspect to be improved is Material quality: the material used for dash board should last for many years and with high wear and tear resistance. The surface quality of dash board should remain glossy for many years and scratch proof. The dash board should less likely to fail with continuous usage such as nobs, switches and glove box and should be free from maintenance. From the analysis we can see that 
the customer have given more weightage for material quality and one of the important characteristic among other customer requirements.

2. The second factor which plays important role is vibration and durability: the dash board should be enough rigid to sustain vibration while driving in rough road or at high speed. The trim quality of the dash board can be improved by changing the specific dimensions. The product features should list long lifespan and lightweight material as technical description for durability can be achieved by material selection. From the house of quality deployment we can see that the company need to improve in this sector.

3. The third factor is, user friendly of the electronic components, more features fewer commands and economical: the electronic components used in the dash board should be comfortable and convenient to use for the passenger. In this area we need to improve and make the electronic USB ports more suitable to use and need to be modified. In these areas the company can have added advantage against competitors. By giving plenty of features it's easy for the customer to understand and use. Customers really like more features and appreciate if it is loaded in the car and which is user friendly. As a result, by making control system friendlier user interface with more features the company can get added advantage with the other company.

In the above context the company should improve from other companies and make the product more unique. We calculated according to the weightage and multiplying the customer index to the factors which are assigned by the importance. The above factor will help to improve the design characteristics and innovate to make it more competitive. This is achieved by using target value that will rate accordingly to the customer perspectives to increase the competitiveness.

\section{CONCLUSION}

Overall, the above discussion about the Quality Function Deployment is a perfect method to solve the current problem and particularly the house of quality matrix which is effective approach to satisfy the customer expectation and design the product accordingly. With this QFD process the problem caused in the car dash board is solved from the customer point of view and is been highlighted. In highly competitive market it is important to survive for any company to make good business strategies and provide high quality product according to customer expectations. QFD helps translating the voice of customer into design requirements, guideline for product development process and improves the success rate of new product. From the above analysis, we get to know the company's strength and weakness points in the product development of car dash board system. This process will help to know where the company lacks in their product.

Three important development in car dash board, material quality, reduce vibration and noise and Electronic USB ports should be in right place and convenient to use are made according to the customer's expectations. The material quality was not up to the mark, it needs to be improved and trim quality need to be improved. The standardised actions to be taken and matched customer's requirement, these important factors are shortlisted and finalised form HOQ matrix. The new product development requirements are identify from market survey and voice of the customer is converted into customer's requirements (WHAT). Product technical specification should be achieved by customer needs (HOW). HOQ matrix is developed with the relationship between WHAT'S and HOW'S. Therefore, meeting customer demands means more than improving product performance. The purpose of translating customer voice is used from initial stages of the product from the design stages to the planning and 
production of the product and then marketing. There are many advantages of QFD such as short development cycle, less engineering changes and initial costs. QFD forces the company to make the product according to customer requirement and also other improvement should also be taken into consideration. The company can desire to grow in highly competitive market and generate profits by improving their standards on basis of customer view. Hence, it can be concluded that quality function deployment is the best tool and suitable for this paper or report.

\section{RECOMMENDATION ACTIONS}

The recommendation actions for the following area to be considered where company can overcome and can catch up to their competitors.

- Based on the Quality Function Deployment analysis results, the material property of the car dash board should be improved in terms of plastic quality, texture and colour. This will help to look the interior more graceful and attract the customer. The texture of the plastic should give the premium look and the colour should match with the other interiors. The materials recommended are polypropylene, styrene maleic anhydride, polycarbonate and acrylonitrile butadiene styrene. This development in the car dash board can help the company to catch up their competitors.

- The dimensions should be maintained accurately so that the finish can be acquired. The trim quality of the dash board should be improved and taken care according to the customer's requirements.

- The material for car dash board should be used which is enough strong and rigid to sustain the vibration and should not produce noise

- The material used for the car dash board should be light weight so that there will be better fuel efficiency. The customer will be more satisfied if they get better fuel efficient vehicle. Approximately $7 \mathrm{~kg}$ of plastic used for car dash board to manufacture, this can be reduced by 1 or $2 \mathrm{~kg}$ by using different kinds of materials. Company should develop light weight products and cars this will be added another advantage for the company. Light weight products or cars can only help the company to exceed from another company and to get a good position in the market.

- The material used for the car dash board should be high durability. The customer needs high wear and tear resistance because the switches, knobs and glove box are regularly / number of times used in a day. The company should bring up with good material quality which consists of high durability property such as polycarbonate or polypropylene. By changing the material property the company can satisfy the customer needs and increase the sales.

- The electronic ports such as USB and others ports should be in right place and convenient to use. The company needs to modify the USB port which is installed in the glove box and which is not comfortable to use. The company should modify the current design and replace the place of USB port which can be used by all the passengers inside the car because these days USB ports have wide scope to use. This is one of the customer requirements which need to be redesigned by the company to attract the customer and catch up their competitors.

- The glove box should have enough storage passage is one of customer requirement. This can be achieved by increasing the inner dimensions and modifying the current design.

- The instruments panel and other electronic devices, switches and ports should be upgraded frequently as technology changes. The car dash board system attracts more customers with more number of features given and with updated version. 
- Continue to collect the data by using questionnaires method from customer which is very important. As a result, acquirements of information can become advantage in the market.

\section{REFERENCES}

[1] Hamidullah, R. Akbar, S. Noor, W. Shah \& Inayatullah, "QFD AS A TOOL FOR IMPROVEMENT OF CAR DASHBOARD", Journal of Quality and Technology Management, 2010, Vol.6, issue. 1, pp1-22. http://pu.edu.pk/images/journal/iqtm/ PDF-FILES/paper-1-Volume_VI_Issue-1-June-2010.pdf

[2] Akao, Yoji (1994). "Development History of Quality Function Deployment". The Customer Driven Approach to Quality Planning and Deployment. Minato, Tokyo 107 Japan: Asian Productivity Organisation. P. 339.

[3] Akao, Y. (1990), "Quality function deployment: A literature review", European Journal of Operational Research, Vol. 143, pp. 463-497

[4] Chan, L.K. and Wu, M.L. (2002), "Quality function deployment: A literature review”, European Journal of Operational Research, vol. 143, pp.463-497.

[5] Cohen, L. (1995), "Quality Function Deployment: How to Make QFD Work for You", 1st Edition. Prentice Hall, New Jersey.

[6] Dean, E.B. (1998), "Quality function deployment: From the perspective of competitive advantage", available at: http//akao.larc.nasa.gov/dfc/qfd.html.

[7] Day, R.G. (1993), "Quality function deployment: Linking a company with its customers", ASQC Quality press, Milwaukee.

[8] Franceschini, F 2002, advanced quality function deployment, St. Lucie Press, Boca Raton, Fla.

[9] Guinta, L.R \& Praizler, N.C(1993): The Qfd book- The team approach solving problems and satisfying customers through Quality function deployment, New York: Amacom

[10] Hunt, RA \& Killen, CP 2004, Best practice quality function deployment (QFD) cases, Emerald Group Pub., Bradford, England.

[11] Hauser, J. R., and Clausing, D. 1988. The House of Quality. Harvard Business Review May- June: 63-73.

[12] http://en.wikipedia.org/wiki/Computer-aided_design

[13] Bossert, J.L. (1991). Quality Function Deployment: A Practitioner's Approach (1st ed.). CRC Press. https://doi.org/10.1201/9781003066545

[14] Martins, A. and Aspinwall, E.M. (2001), "Quality function deployment: an empirical study in the UK", Total Quality Management, Vol. 12, No. 5, pp. 575-588.

[15] Quality Function Deployment - University of Warwick.

[16] Sullivan, L.P. (1986), “Quality Function Deployment”, Quality Progress, June, pp 39-50.

[17] Praveen Padagannavar and Manohara Bheemanna. Automotive Computational Fluid Dynamics Simulation of A Car Using Ansys, International Journal of Mechanical Engineering \& Technology, 7(2), 2016, pp. 101-114.

[18] Praveen Padagannavar. Computational Engineering of Finite Element Modelling for Automotive Application Using Abaqus, International Journal of Advanced Research in Engineering \& Technology, 7(2), 2016, pp. 30-52. 